Article

\title{
Shocks, Resilience and Structural Transformation in Sub-Saharan Africa
}

\author{
Adesoji Adelaja *, Justin George $\mathbb{B}$, Louise Fox, Keith Fuglie and Thomas Jayne
}

check for updates

Citation: Adelaja, A.; George, J.; Fox, L.; Fuglie, K.; Jayne, T. Shocks,

Resilience and Structural

Transformation in Sub-Saharan

Africa. Sustainability 2021, 13, 13620.

https://doi.org/10.3390/su132413620

Academic Editor:

Francesco Caracciolo

Received: 30 September 2021

Accepted: 30 November 2021

Published: 9 December 2021

Publisher's Note: MDPI stays neutral with regard to jurisdictional claims in published maps and institutional affiliations.

Copyright: (c) 2021 by the authors. Licensee MDPI, Basel, Switzerland. This article is an open access article distributed under the terms and conditions of the Creative Commons Attribution (CC BY) license (https:// creativecommons.org/licenses/by/ $4.0 /)$.
Department of Agricultural, Food and Resource Economics, Michigan State University, 204 Morrill Hall of Agriculture, 446 West Circle Drive, East Lansing, MI 48824, USA; kappiaru@msu.edu (J.G.); fox.louise@outlook.com (L.F.); keith.fuglie@usda.gov (K.F.); jayne@msu.edu (T.J.)

* Correspondence: adelaja@msu.edu; Tel.: +1-517-884-8521

\begin{abstract}
Evidence of how resilience factors mitigate the adverse effects of shocks on individuals, households and communities is clearly established. However, such evidence at the macro level is limited, especially on the pace of structural transformation. This paper explores whether the growing incidence of terrorism, armed conflicts and natural disasters in SSA impeded the pace of structural transformation. We conceptualize the notion of macro-resilience and test whether resilience factors mitigate the adverse effects of shocks on two measures of structural transformation: agriculture's share of GDP and of national employment. We find that structural transformation is impeded by armed conflict and terrorism-related shocks but not natural disasters and that resilience factors enhance the pace of agricultural transformation. This implies that, while agriculture is often destroyed in conflict-affected areas, the broader impacts are even more negative for other sectors of the economy. However, surprisingly, we find negative or insignificant interaction terms between the shock and resilience variables, implying no mitigative role of resilience capacities. This may suggest, in the case of conflicts and terrorism, the presence of major, debilitating effects which limit the mitigative capacity of resilience factors. We further explore the implications for future research and possible strategies to address the growing threats from shocks.
\end{abstract}

Keywords: structural transformation; resilience; conflict; natural disasters; shocks; terrorism

\section{Introduction}

Sub-Saharan Africa (SSA) has been at the center of global economic development interests since the independence of its nations in the late 1950s and early 1960. Despite its significant natural and human resource endowments, following their independence, many SSA economies faced significant growth and development challenges. For example, as highlighted by Jayne et al. [1] and Adelaja et al. [2] and shown in Figure 1, the average real per capita income in SSA countries fell almost consistently between their independence and the mid-1990s. While generally attributed to limited infrastructure and experience and legacy issues from the days of colonization [3], such poor performance raised concerns at the end of the 20th century about prospects for structural transformation and sustained economic development in SSA $[4,5]$ and whether the region could eventually become self-reliant.

The prospects for SSA improved dramatically since about the year 2000 when the region began two decades of sustained and transformative economic growth. For example, real per capita income grew every year from 2000 to 2016 [1] as average education levels rose [6]. SSA also became the world's second fastest growing regional economy, surpassed only by Asia [6]. Poverty rates declined as the proportion of the region's population with incomes below the USD 1.90 per day (poverty rate) fell from 54\% in 1990 to 41\% in 2015 [7]. Nutritional indicators also showed gradual but marked improvement [8]. Women became considerably more active in labor markets [9] and gained greater influence over household 
resources [10]. Measures of financial inclusion also improved rapidly [11]. The post2000 reversal of fortune has been mainly attributed to improved governance and political liberalization, debt restructuring and a subsequent increase in public expenditures on social services, greater domestic and foreign direct investment in many sectors, improved fiscal and monetary policies, reductions in distortionary economic policies and enhanced overall policy environment $[12,13]$.

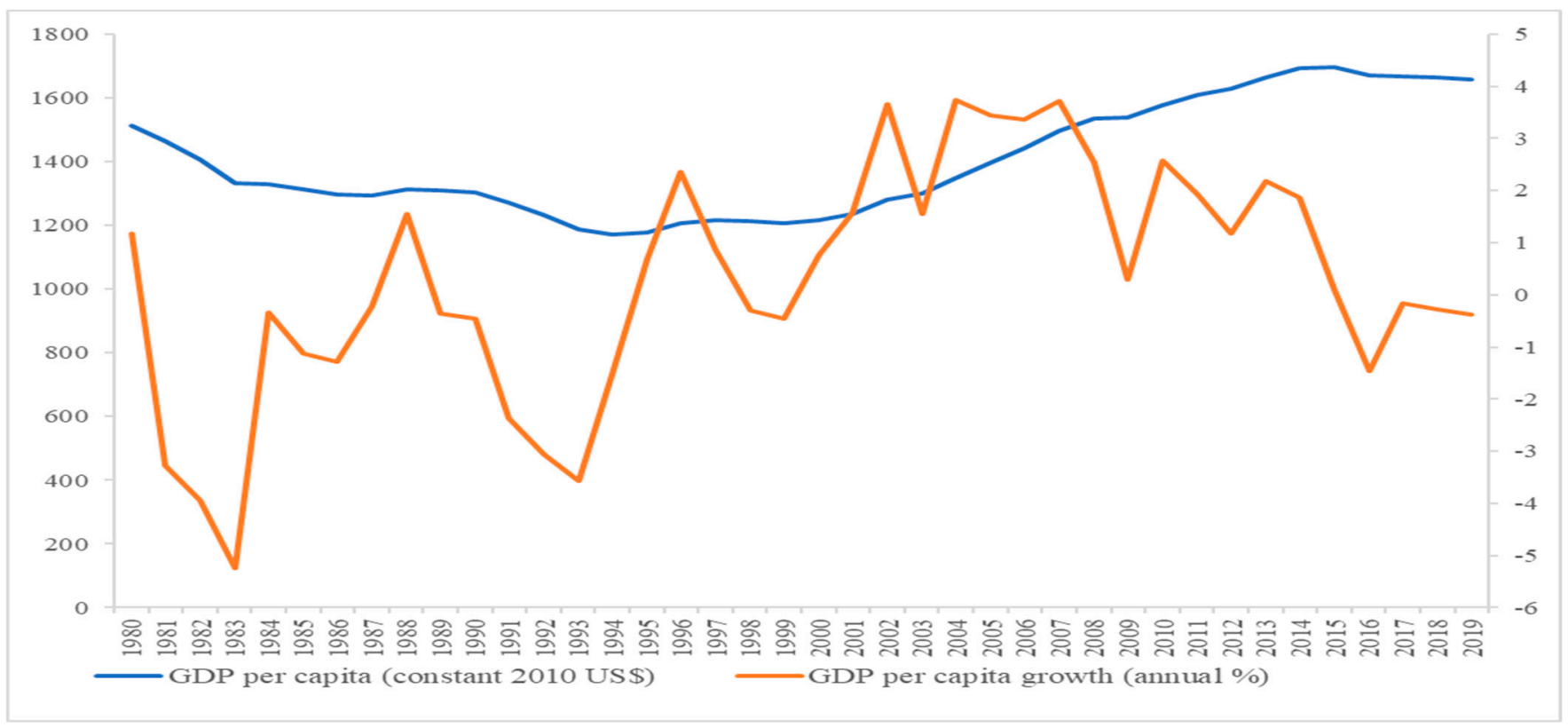

Figure 1. GDP per capita vs. GDP per capita annual growth rate for SSA, 1980-2018 (constant USD 2010). Source: World Bank (2019). World Development Indicators, low- and middle-income countries only.

While these fundamental reforms put many countries on an improved growth path, SSA remains the world's least developed region today. For example, with about 25 percent of its people being undernourished, SSA also accounts for over 25 percent of the world's undernourished and over 50 percent of its poor [14]. Hence, significant aid and donor support have been targeted toward SSA. Today, this region is the most aid-dependent in the world [7]. Many SSA countries also face infrastructure deficits and institutional deficiencies that date back to the colonial period [12]. In addition, at least two decades of development opportunities were lost as per capita GDP in SSA only returned to its 1980 level in 2008.

The unique pattern of growth in SSA during the past two decades has also raised a few questions about whether structural transformation, defined as the reallocation of economic activity (and factors of production) from low-productivity activities to higher-productivity activities, thus raising overall productivity in the economy, is really occurring. In SSA, the 2000 to 2018 period was one of significant progress in agriculture. According to the World Bank [11], between 2000 and 2018, SSA achieved the highest rate of agricultural production growth of any region of the world (4.3 percent per year average). However, non-agricultural sectors grew even more rapidly and, as a result, agriculture's share in GDP declined [1]. The share of the labor force in non-farm employment also increased since 2000 as SSA's rural labor force diversified away from subsistence farming [15]. This contributed to the region's rising labor productivity $[16,17]$. However, unlike the transformation process in other regions, SSA's growth involved little industrialization and more direct leapfrogging from agriculture to the service sector $[9,12,18]$. This raises questions about whether SSA's growth is stable, sustainable and resilient enough to achieve future self-reliance.

The growing incidence of extraneous shocks from armed conflict (e.g., terrorism in the Sahel), natural disasters (e.g., storms), climate (e.g., droughts) and recent health shocks (e.g., Ebola and the recent COVID-19 pandemic) raise further questions about the 
sustainability of SSA's progress toward structural transformation [19-21]. This is especially so because agriculture, which underpinned recent growth, has borne the brunt of many of these shocks. Armed conflicts have increased in prevalence and lethality in SSA [22-26]. For example, the number of armed conflict incidents in SSA countries increased eightfold between 1997 and 2000 from 2826 to 23,721, while associated fatalities increased from 20,118 to 36,154 [25,26]. Armed conflicts have also adversely affected agriculture and aggravated food insecurity at the household level in substantive ways [22,27]. By causing internal (IDPs) and external (refugees) population displacements, conflicts also have adverse spillover effects on host communities, thereby exacerbating the economic problems of places remote from the theater of conflicts [28]. Armed conflicts, therefore, threaten past advancements in economic development, especially in rural areas [29-31].

Likewise, the number of natural disaster incidents rose from 30 in 1990 to 95 in 2020, leading to an increased number of affected people [32]. Between 1991 and 2020, the 2108 natural disaster incidents in SSA killed 191,638 people and affected 419 million people [2,32]. The dominant natural hazards were floods (852 incidents), epidemics (722), storms (203) and droughts (186), but droughts affected the largest number of people (323 million). Climate change also resulted in increased desertification [33], leading to greater incidents of drought [34], more frequent and longer incursion by pastoralists in new territories and more farmer-herder conflicts [27]. Many countries, especially resource-dependent ones, were also exposed to shocks from low and unstable commodity prices. For example, between June and December 2014, the Brent price of crude oil fell by $44 \%$, resulting in one of the most dramatic declines in the price of oil in recent history and creating major challenges for the economies of Nigeria, Angola and other oil-producing countries.

The COVID-19 pandemic resulted in massive economic slowdowns and exposed the vulnerabilities of African farmers and other poor people working in the informal sector who have little job or food security $[35,36]$. According to initial UN estimates, at a minimum, an additional 83 million people, and possibly as many as 132 million, went hungry in 2020 due to the economic recession triggered by COVID-19 [37]. In SSA, 14 countries are at high risk of or were already experiencing significant food security deteriorations, including rising numbers of people pushed into acute hunger [38]. Declining employment and wages mean that households have less money for food and household goods [38]. All of these suggest the need to more deeply explore the impacts of shocks on the pace of structural transformation.

The shocks described above also raise concerns about the resilience of SSA's economies. Resilience implies responding to avoiding loss of income and assets when shocks occur by building the needed capacity to protect the viability of households and enterprises [2] and, by extension, macroeconomies. Without resilience, there is a potential to lose past advancement, which cost much to achieve, and for some economies to go off-track. Hence, progress toward structural transformation must be examined in the context of resilience.

Whether or not the growing incidence and severity of shocks have slowed down the pace of structural transformation is therefore an important research question. So is the role of resilience in safeguarding structural transformation in SSA countries. The micro-level impacts of extraneous shocks (on household development outcomes) have been well documented in the literature. These micro-level studies demonstrate the importance of resilience in mitigating the impacts of shocks $[39,40]$. However, the impacts of shocks on the process of structural transformation and the role of resilience capacity in mitigating such impacts and in safeguarding the progress made by SSA countries in structural transformation have received little empirical attention, although several studies allude to them. The issue of structural transformation is most relevant in developing countries because they are the ones still heavily dependent on agriculture. However, research focusing on the role of shocks in moving the trajectory of structural transformation focuses is scant. While there are some studies which focus on the endogenous relationship between structural transformation and armed conflicts [41-43], they focus mainly on how countries with a large share of agriculture are more conducive to armed conflicts, not the other way around. 
In light of the above, this paper explores three important, intertwined concepts regarding sustainable growth in SSA: the relationships between resilience, agriculture's progress and progress toward structural transformation. The specific objectives are threefold: to (a) provide empirical evidence on the impacts of key shocks on the pace of structural transformation, (b) develop indices of resilience to these shocks and (c) investigate the possible role of these resilience indicators in mitigating any adverse effects.

We combine cross-country panel data from the years 2000 to 2018 on various shocks $[25,26,32,44]$ with data on development indicators [11] to create a database for measuring the impacts of these shocks, constructing resilience indicators using the factor analysis approach and examining the mitigation effects of resilience factors. We use two proxies as dependent variable indicators of the pace of structural transformation: nonagricultural share of (a) GDP and (b) overall employment. Our main hypotheses are that: (a) shocks retard the pace of structural transformation while resilience indicators bolster it, and (b) resilience factors mitigate the adverse effects of shocks on structural transformation.

We organize the rest of this paper as follows. In Section 2, we briefly review the extant literature on the two related concepts of structural transformation and resilience and summarize potential linkages between them. In Section 3, we provide a simple conceptual framework for exploring these relationships. In Section 4, we present the methodology, which includes the empirical model for testing the relationships between shocks, resilience factors and our two indicators of structural transformation. We also provide the description of the data and our estimation techniques. In Section 5, we present our empirical results. Section 6 provides the summary and conclusion of the paper and presents some policy implications.

\section{Shocks, Resilience and Structural Transformation}

In Section 2, we briefly review the related concepts of agricultural development, structural transformation, resilience and sustainability and explore how shocks affect these relationships. We also review existing evidence on the impacts of shocks and the role of resilience in mitigating their adverse effects. Because the literature on the role of resilience factors in mitigating the macroeconomic impacts of shocks on the pace of structural transformation in Africa is not well developed, we leverage the literature on resilience at the individual, household and community levels in developing a conceptual framework for evaluating the role of resilience factors in mitigating the impacts of shocks at the scale at which we measure both shocks and structural transformation.

\subsection{Structural Transformation and Sustainability}

Structural transformation, a macroeconomic concept, reflects an overall change in the allocation of resources in an economy. It is the process by which a continent, region, country or sub-national entity moves the share of labor and other resources from lower- to higher-productivity sectors as it grows, thereby increasing economic opportunities and the general level of prosperity and reducing poverty $[1,13,45-47]$. Structural transformation is an appropriate evaluation framework for SSA economies since most of them started with low-productivity agriculture as the dominant sector and an overall low level of aggregate labor productivity and material welfare. By moving the share of employment off the farm to higher productivity and earnings in growing industrial and service sectors, a nation increases its capacity to produce goods and services by shifting resources from agriculture (a traditional, household-based, low-productivity sector) toward more modern, enterprise-based, high-productivity sectors, while simultaneously increasing productivity in all sectors [1]. Such structural transformation is a fundamental mechanism underlying economic development.

Structural transformation is a prerequisite for sustainable economic development, a process to accomplish it and a measure of its progress. This is because it raises the general level of productivity, wages and income, thereby enhancing economic opportunities and overall prosperity [45]. Faster growth in the capacity to produce goods and services than in 
population is necessary to achieve effective transformation and sustainable development because these require continual investment, which further requires increased resources per capita. Income growth is a necessary but not sufficient condition for sustainable development and progress toward self-reliance. Sustainable development requires much more than growth and must be accompanied by transformation to allow the gains to be maintained-to be resilient.

All advanced economies and many recently transformed ones started with agriculture as a foundational industry [47]. Through advances in skills and technology, the earnings of agricultural workers and others employed in rural areas rose. However, as other sectors (such as manufacturing and services) grew, they attracted a growing share of the increases in labor and capital, thereby growing economy-wide earnings, income and prosperity [47]. Many economists, therefore, came to see the movement of human capital from agriculture (a low-productivity sector) to the industrial or service sectors (higher-productivity sectors) as a prerequisite or marker for real economic progress [46].

Structural transformation, especially at the start of the process, relies on productivity growth in agriculture through continual investment and innovation, as well as on increased investment and technology development in non-agricultural sectors $[1,46]$. Policies to support structural transformation include: macroeconomic and political stability, greater integration into the global economy, an enabling business environment, financial deepening and inclusion, developing entrepreneurism, increasing the supply of adequate social and infrastructure services and rapid and effective demographic transition (see Jayne et al. [1]). Many SSA economies are still under-developed, requiring progress in structural transformation to make them more self-reliant. Enabling structural transformation is, therefore, a key policy goal of SSA governments and their development partners.

Prominent measures of progress toward structural transformation include the share of GDP generated by agriculture vs. non-agricultural sectors, the share of overall employment attributable to agriculture vs. non-agricultural sectors and the rate of growth in economywide productivity. Data on the third measure are not always consistently available or reliable. The other two have an inverse relationship with structural transformation. As a nation matures, resources previously devoted to agriculture (labor, skills and financial and physical capital) must be redistributed to other sectors as part of the economic diversification process. In the process, agriculture will grow, but other sectors will grow faster. However, since agriculture is often the lower-productivity sector, effective transformation will result in the redeployment of these resources to other higher-productivity sectors. So, two direct proxies for structural transformation are the shares of GDP and aggregate labor contributed by other sectors. Notably, the former increases much faster than the latter owing to the need for increased capital and technology to increase higher-productivity employment [43].

\subsection{Resilience and Sustainability}

Resilience can be defined as the capacity of a system to cope with expected or unexpected hazardous events by responding in ways that maintain its essential identity, structure and function, as well as maintain its capacity to adapt and learn. Here, in the context of structural transformation, we follow the definition of Adelaja et al. [2], modifying it a bit. That is, "resilience is the capacity of a country to dampen the impact of shocks, quickly recover, get back on track with its transformation trajectory, and improve on the ability to withstand future perturbations". Resilience, which is synonymous with the concepts of "recovery", "bounce-back" and "building back better", is also a key requirement of sustainability, as the lack of resilience means the inability to sustain progress.

As shown in Figure 2, a non-resilient system will depart from its sustainable growth path for a longer period, vis-à-vis a resilient system. As argued by Fox, Jayne and Moskaleva [48], resilience, like sustainability, involves the economic, social and environmental domains and is often a latent variable that is difficult to measure. It is both a microeconomic and macroeconomic concept. At the macroeconomic level, the sustained 
growth brought about by structural transformation can increase resilience or the ability of a country to mitigate the effects of shocks, as can the deliberate building of resilience capacity to specific shocks [49].

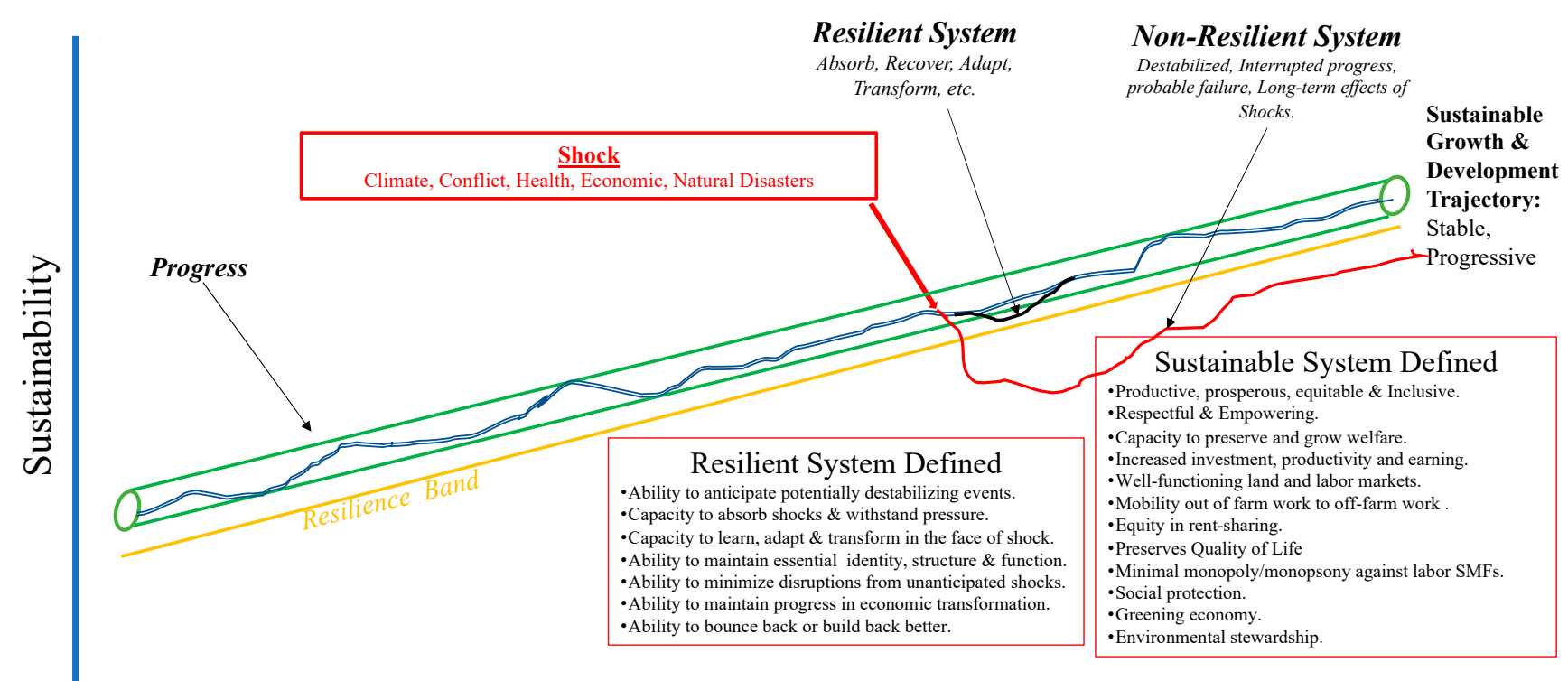

Time

Figure 2. Resilience and Sustainability.

Resilience mitigates the impacts of a shock in several ways. Here, we highlight a few. First, the risk of a shock can be minimized through shock prevention-reducing the probability that a shock will occur. This requires the development of preventative mechanisms, such as effective public health surveillance systems to prevent a pandemic from developing. Second, the adverse effects of a shock can be minimized through shock mitigation-reducing the impact of a future shock. This requires the development of adaptive and absorptive capacities to dampen the effects of shocks (e.g., drought-resistant varieties in the case of a drought or hardening infrastructure to prevent damage when a natural disaster occurs). Third, negative effects can be minimized through coping. Coping actions may include programs to provide cash or in-kind transfers to those affected by a shock (e.g., social safety nets). Above all, risks and negative outcomes can be minimized through transformative capacity. This requires the development of the capacities to see shocks as opportunities to change, leapfrog and shift one's growth paradigm.

In light of the growing exposure to the shocks, interest in the concept of resilience has grown in recent years. Programs centered around resilience have also grown significantly. The concept has gained interest in the design/implementation of programs by development agencies such as the USAID and the DFID. For humanitarian programs, resilience translates into avoiding repeated humanitarian and reconstruction interventions. Building resilience to shocks can reduce the high human and economic costs associated with repeated humanitarian and rebuilding efforts and the associated political and public pressures [2].

In the context of structural transformation, resilience is needed to avoid the destruction of the assets needed to continue structural transformation. Determining the role of resilience in reducing the negative effects of shocks requires identifying appropriate measures of structural transformation (as endogenous variables), measuring the intensity of the shocks (as independent variables) whose effects are being evaluated, constructing measures of the latent resilience variable (as mitigative factors) and examining the effects of selected shocks on measures of structural transformation with and without the mitigative role of resilience factors. 


\subsection{Shocks and Resilience}

Shocks can be defined as "sudden extraneous events that can cause short-term deviations from long-term trends that have substantial negative effects on people's current state of well-being, level of assets, livelihoods and safety" [50]. Examples include various forms of natural hazards (e.g., floods, droughts and pests), armed conflicts (e.g., ethnic violence, farmer-herder conflicts and communal clashes), health shocks (e.g., epidemics and pandemics), terrorism and macroeconomic volatility (e.g., exchange rate volatility, commodity price hikes and recessions). Likewise, we define stressors as "long-term trends or pressures that undermine the stability of a system and increase vulnerability within it" [51]. Examples include climate change, erosion, population pressure and protracted political instabilities.

In our analysis, we focus on the key shocks which grew significantly in incidence and impact since the year 2000, namely (a) armed conflicts, (b) natural disasters and (c) terrorism. The number of armed conflict incidents in SSA (inclusive of terrorism incidents) rose by almost 700\% between 1991 and 2020, while the resulting fatalities almost doubled [25,26]. For natural disasters, they show a 140 percent increase in incidents. These make Africa the second most exposed continent in exposure to disasters.

The impacts of shocks in SSA and other developing countries are well documented in the literature, especially at the micro and sector levels. Empirical evidence from conflictridden countries hints at the adverse effects of conflict events on productive assets of firms and households and their overall production [22], the outputs of specific crops [22], land-use choices [52], cropping practices [53], food security [54], the nutritional status of children [55,56], labor market outcomes [57] and levels of investments [58]. Armed conflicts, including terrorism, also have indirect impacts on livelihoods, vis-à-vis forced displacement, persistent ethnic and religious tensions, regional instability and a decline in investment by domestic and international investors. As for forced displacement, in both origin and destination communities, the negative impacts on livelihoods [59,60], earnings [61,62] and commodity and land prices [63-65] are also notable.

The negative impacts of natural disasters at the household level have also been well documented in the literature. Natural disasters have been shown to cause notable damage to crops, crop lands, physical infrastructure, houses, livestock and livestock shelters and production tools, equipment and machinery [66-69]. Macro-level pathways for the impacts of natural disasters include destruction of natural resource, physical capital and human capital stocks, social and economic infrastructure and damage to the financial system [70]. The macro-level effects, however, include the disruption of markets, damage to necessary infrastructure, declines in investment and consumption [71] and reductions in food and nutritional security $[72,73]$. In essence, while limited evidence on macro-level effects of shocks exists for Africa, the micro-level studies suggest that shocks related to natural disasters and conflict have significant negative impacts on the level of economic activities in affected countries, especially for SSA economies which are not diversified enough to cope with negative production shocks [74,75].

\section{Conceptual Framework}

From the above, we expect that shocks which affect key microeconomic outcomes can also affect aggregate macroeconomic outcomes. Since agriculture is particularly vulnerable to shocks, one expects these shocks to have the potential to affect the pace of structural transformation by impeding or hastening the necessary processes that underpin structural transformation. For example, the human displacements caused by shocks often dislocate people, thereby retarding or accelerating optimal redeployment of labor. That is, shocks may force inter-sectoral moves by people that are inconsistent with the principle of structural transformation (e.g., move people back to agriculture), or accelerate the process of structural transformation (e.g., force people to explore higher-productivity sectors).

Shocks may also lead to infrastructure, homestead and community destruction, thereby necessitating reinvestment that slows down the pace of asset accumulation neces- 
sary for structural transformation. Alternatively, they can facilitate leapfrog development and building-back-better opportunities. For example, early evidence from the COVID-19 pandemic suggests that agriculture grew by providing opportunities for people to redirect their efforts to home-grown food production in order to reduce their exposure and smoothen their incomes [21,76], but it also accelerated the development of e-commerce. Shocks can also alter planning horizons and distort investment patterns by changing the geographic distribution of risks and security challenges. The net effects of shocks may be positive or negative, depending on the sector in question.

One of the main reasons why the process of structural transformation is vulnerable to shocks is because of the territorial nature of armed conflicts in SSA. In the case of many civil wars and insurgencies in the region, violent non-state actors impose their will on the government and the public by taking control of the land, primarily in rural areas. For example, at the height of insurgency, Boko Haram controlled a significant share of northeastern Nigeria, a region heavily dependent on agriculture. Similarly, most natural disasters and climate-related shocks also impact land, an immobile asset, meaning that shocks can have a disproportionate effect on the agricultural sector vis-à-vis other sectors.

The relative impact of shocks on structural transformation also depends on the duration of shocks. For example, on average, civil wars last over five years, with many of them lasting for decades. The persistent nature of such shocks means that long-term development indicators including education, health and other social outcomes are negatively impacted, affecting the ability of workforce to acquire new skills. This will prevent inter-sectoral movement of labor and thereby slow down the pace of structural transformation.

If shocks impede the process of structural transformation, by its very definition, resilience helps to mitigate the adverse effects of such shocks. For example, because the lack of resilience implies extended periods of deviation from the normal growth process and repeated humanitarian interventions, resilience building can reduce the high human and economic costs of repeated humanitarian and rebuilding efforts and the associated political and public pressures [28]. The problem, however, is how to select resilience measures that are appropriate to the scale at which shocks and structural transformation are evaluated. Macro-level studies on the selection or measurement of appropriate resilience measures for structural transformation hardly exist. However, the micro-level studies provide some guidance on the types of macro-level variables that can be explored as resilience factors and indicators.

Our empirical strategy is, therefore, to examine the relationships between the levels of selected shocks across SSA countries on the one hand and various indicators of structural transformation on the other hand. Two common indicators of national-level structural transformation include (1) agriculture's share of GDP and (2) agriculture's share of aggregate national employment [46]. Because structural transformation implies a decreasing share of agriculture in (i) national GDP (the output dimension) and (ii) employment (the labor market dimension), to make the dependent variable directly reflective of the progress toward structural transformation there is a need to transpose these two measures. That is, the indicators of structural transformation to be used as dependent variables in our empirical work are (1) non-agricultural share of GDP and (2) non-agricultural share of total employment. However, although both employment and GDP variables track growth trajectories of the economy, employment moves more slowly when compared with the GDP variable. Hence, we may observe evidence of shocks impacting both measures of structural transformation differently.

\section{Empirical Framework}

\subsection{Data}

Data on non-agricultural shares of both GDP and employment for the 2000 to 2018 period are directly obtained from the World Bank's World Development Indicators [6]. As indicated above, there exists numerous possible measures of the intensity of shocks. In our analysis, we zero in on three main shocks whose intensities have grown in recent 
years: (1) terrorism, (2) armed conflicts and (3) natural disasters. To construct the terrorism shock variable, we use the number of terrorist incidents obtained from the Global Terrorism Database (GTD). The GTD records information on terrorism events world-wide, starting from 1970. The GTD defines a terrorist attack as "threatened or actual use of illegal force and violence by a non-state actor to attain a political, economic, religious, or social goal through fear, coercion, or intimidation" [44]. In practice, for an incident to be included in the GTD, all three of the following attributes must be present: the incident must (1) be intentional-the result of a conscious calculation on the part of a perpetrator, (2) entail some level of violence or immediate threat of violence, including property violence, as well as violence against people and (3) involve perpetrators who are sub-national actors.

We measure the intensity of armed conflicts by the number of incidents that took place in each country annually. This variable is constructed using ACLED, which provides data on armed conflict events and non-violent protests in Africa and Asia by location [26]. ACLED codes the actions of actors (such as government, ethnic groups, active political organization, civilians and militias), date of battle events, time precision, interaction type, number of fatalities, latitude and longitude. In terms of attack types, it covers violent activities such as remote violence against civilians, militia interaction, protests, riots, remote violence and battles. Finally, to measure the intensity of natural disasters, we use the Emergency Events Database (EM-DAT) [32]. The EM-DAT is a free and fully searchable database that contains world-wide data on the occurrence and impact of over 20,000 natural and technological disasters from 1900 to the present day. EM-DAT provides an objective basis for vulnerability assessments and rational decision making in disaster situations.

Recall that the basic premise of our analysis is that shocks have the potential to retard the pace of structural transformation but that resilience factors may mitigate these impacts. Recall also that, while the literature on micro-level resilience is much advanced, little guidance exists on the measurement of macro-level (e.g., national) resilience [77]. In line with our earlier definition of resilience, for empirical purposes, the Resilience Measurement Technical Working Group defines resilience as "the capacity that ensures adverse shocks do not have long-lasting adverse development consequences" and identifies the importance of absorptive, adaptive and transformative capacities in building resilience [78]. Being core components of micro-resilience [39,77-79], these capacities provide a framework for exploring components of macro-resilience. At the national level, specific absorptive, adaptive and transformative capacity elements may include access to basic services (e.g., health, water and electricity), asset holdings (e.g., land, real estate, livestock and savings), social and human capital, exposure to information, livelihood diversity, safety nets and quality of governance (for example, see Smith and Frankenberger [40] or Broadberry and Wallis [78]).

In this context, there are several potential measures of macro-resilience. We select 11 such measures based on the extant literature $[30,80]$ that reflect how basic human, economic, institutional and infrastructure progress contribute to resilience building at the national level. The choice of these measures is based on their importance to economic development in the context of SSA and data availability. To reduce the potential for multi-collinearity and tease our more coherent resilience measures, we then use the factor analysis approach to reduce the number of resilience variables from 11 to 3 . Rather than force each of the 11 specific measures into categories, we allowed the factor analysis process to sort out and select the categories.

Six of the eleven original variables are extracted from the World Development Indicators by World Bank [11]. One of the eleven variables, access to electricity, measured as the percentage of population with access to electricity in a country, reflect the level of physical infrastructure development in a country [77]. It also shows whether the benefits of economic development have reached rural areas, which are primarily dependent on agriculture. It is expected to contribute to the pace of structural transformation and mitigate the effects of adverse shocks. 
Another major asset that may reflect a country's resilience capacity is the availability of agricultural land. The agricultural land variable is measured as the share of land area that is arable, under permanent crops and under permanent pastures, primarily based on the definition by the FAO [30]. In the context of SSA, land available for cultivation represents the level of economic resources and assets in a country and their ability to bounce back in the event of a shock. Trade openness, which connotes national flexibility and may reflect the degree of national adaptiveness, is measured as the sum of exports and imports of goods and services as a share of GDP [30]. Countries with better trade networks with other countries have better prospects of external assistance in their attempts to cushion the negative effects of shocks. Better health systems are expected to facilitate structural transformation and mitigate the effects of shocks. The health expenditure variable may reflect absorptive capacity [77]. It is measured as the level of current health expenditure as a percentage of GDP. Estimates of current health expenditures include healthcare goods and services consumed; however, it excludes capital health expenditures such as buildings, machinery, IT and stocks of vaccines for emergency or outbreaks. In the event of shocks such as pandemics, the level of health infrastructure is a good measure of a country's bounce-back capabilities.

The FDI variable refers to direct investment equity flows in a given economy. It is the sum of equity capital, reinvestment of earnings and other capital. FDI may reflect adaptive capacity, but transformative capacity as well [30]. Finally, education as an asset may contribute to absorptive and adaptive capacity. The net primary school enrollment rate is measured as the ratio of children of official school age who are enrolled in school to the population of the corresponding official school age [7].

We also use five governance indicators from the World Governance Indicators (WGI) database as indicators of absorptive, adaptive and transformational capacity [11]. WGI compiles country-level information about the nature of governance from multiple existing data sources, which record perspectives of a representative sample of citizens, entrepreneurs and experts from various sectors. In many developing countries, the dominance of public sector in strategic areas means that it is imperative to have good governance structure in order to build resilience. Good governance ensures a process of decision making that is accountable, transparent, just, responsive and participatory at state, community and individual levels. The voice and accountability variable captures perceptions of the extent to which a country's citizens are able to participate in selecting their government, as well as freedom of expression, freedom of association and a free media. The political stability variable measures perceptions of the likelihood of political instability and/or politically motivated violence, including terrorism. The government effectiveness variable captures the quality of the government institutions and consistency in implementation of policy decisions. The regulatory quality variable represents public perceptions about the ability of the government to design and execute good policies and regulations that promote economic development. Finally, the control of corruption variable is the measure of red-tapism and the likelihood of encountering corrupt officials. Summary statistics for all the variables used in the analysis are shown in Appendix A Table A1.

\subsection{Empirical Strategy}

We empirically estimate the impacts of shocks on economic growth and the structural transformation of the economy for 45 SSA countries from 2000 to 2018. For the same sample, we also examine whether resilience factors mitigate the negative impacts of shocks on the structural transformation variables. We used fixed effects regressions to estimate the empirical models. A fixed effects model allows us to control for the time invariant country-level factors which could potentially bias the estimation results.

Our empirical analysis consists of mainly two steps. First, to understand the association between resilience capacity, economic development and structural transformation in the presence of shocks, we specify and estimate the following:

$$
Y_{i t}=\alpha+\beta S H_{i t}+\gamma R C_{i t}+\delta X_{i t}+\mu_{i}+\tau_{t}+\epsilon_{i t}
$$


where $Y_{i t}$ represents the two structural transformation variables, $S H_{i t}$ represents the shocks and $R C_{i t}$ represents the resilience capacity of a country $i$ in year $t$. All variables that measure resilience are lagged by one year to control for potential sources of endogeneity. $X_{i t}$ represents the vector of country-level time-varying control variables which explain the dependent variable. Country fixed effects control for the time-invariant country-level variables which explain the dependent variable. $\alpha, \beta$ and $\gamma$ represent the coefficients to be estimated. $\mu_{i}$ and $\tau_{t}$ represent country and year fixed effects, respectively.

Structural transformation of an economy is measured using two measures: (1) percentage contribution of the non-agricultural sector to the GDP and (2) percentage contribution of the non-agricultural sector to employment. Three different shock variables are used in the analysis: (1) number of armed conflict incidents, (2) number of natural disasters and (3) number of terrorism incidents. We use both individual indicators and factor analysis indices to measure resilience capacity.

For the factor analysis technique, we choose a baseline of indicators based on the theoretical understanding of how these variables contribute to building resilience capacity. We choose the number of factors based on the Kaiser-Meyer-Olkin (KMO) statistic (factors with value greater than or equal to 0.5 are retained).

Second, we estimate how various resilience factors mitigate the negative impacts of shocks on structural transformation variables. The estimating equation is expressed as:

$$
Y_{i t}=\alpha+\beta S H_{i t}+\gamma R C_{i t}+\rho\left(S H_{i t} * R C_{i t}\right)+\delta X_{i t}+\mu_{i}+\tau_{t}+\epsilon_{i t}
$$

The equation is similar to equation (1), except for the interaction term between shocks and resilience capacity. A statistically significant and positive coefficient of the interaction term will provide evidence in support of the mitigating effects of resilience capacity on shock. All regressions are estimated using the OLS-FE estimation technique. Summary statistics for all the variables included in the analysis are reported in Appendix A Table A1.

\section{Empirical Results}

In Tables 1-3, we present the results for the impacts of three major types of shocks (armed conflicts, natural disasters and terrorism) on economic growth and structural transformation of SSA countries. We also examine how resilience factors mitigate the negative impacts of such shocks on the pace of structural transformation. To derive the measures of resilience, we mainly use the factor analysis technique, whereby a multitude of macroeconomic variables are reduced to three main factors, each representing an important dimension of resilience. The two main dependent variables, percentage contribution of the non-agricultural sector in GDP and employment, are then regressed on the resilience factors and their interactions with shock variables to test the hypotheses discussed in Section 2. 
Table 1. Impacts of conflict shocks and resilience factors on structural transformation.

\begin{tabular}{|c|c|c|c|c|c|c|}
\hline & (1) & (2) & (3) & (4) & (5) & (6) \\
\hline & \multicolumn{3}{|c|}{$\%$ of Non-Agriculture in GDP } & \multicolumn{3}{|c|}{$\begin{array}{c}\% \text { of Non-Agriculture in } \\
\text { Employment }\end{array}$} \\
\hline Conflicts & $\begin{array}{l}-1.130 * * \\
(-2.27)\end{array}$ & $\begin{array}{l}-0.921^{* *} \\
(-2.55)\end{array}$ & $\begin{array}{l}-0.626 \\
(-1.24)\end{array}$ & $\begin{array}{l}-0.710 \\
(-1.22)\end{array}$ & $\begin{array}{l}0.345 \\
(0.82)\end{array}$ & $\begin{array}{l}0.207 \\
(0.35)\end{array}$ \\
\hline Governance factor & $\begin{array}{l}1.912^{* * *} \\
(3.73)\end{array}$ & & & $\begin{array}{l}0.481 \\
(0.78)\end{array}$ & & \\
\hline Socio-economic assets factor & & $\begin{array}{l}1.235^{* *} \\
(2.28)\end{array}$ & & & $\begin{array}{l}1.117^{*} \\
(1.75)\end{array}$ & \\
\hline Economic and political stability factor & & & $\begin{array}{l}-0.325 \\
(-0.97)\end{array}$ & & & $\begin{array}{l}-0.531 \\
(-1.34)\end{array}$ \\
\hline (Governance factor) X (conflicts) & $\begin{array}{l}-0.226 \\
(-0.44)\end{array}$ & & & $\begin{array}{l}-1.346^{* *} \\
(-2.25)\end{array}$ & & \\
\hline (Socio-economic assets factor) X (conflicts) & & $\begin{array}{l}0.424 \\
(0.75)\end{array}$ & & & $\begin{array}{l}0.488 \\
(0.75)\end{array}$ & \\
\hline (Economic and political stability factor) $\mathrm{X}$ (conflicts) & & & $\begin{array}{l}0.667 \\
(1.31)\end{array}$ & & & $\begin{array}{l}0.155 \\
(0.26)\end{array}$ \\
\hline $\log ($ population) & $\begin{array}{c}10.34^{* * *} \\
(3.46)\end{array}$ & $\begin{array}{l}9.456^{* * *} \\
(3.15)\end{array}$ & $\begin{array}{l}9.388^{* * *} \\
(3.11)\end{array}$ & $\begin{array}{c}10.42^{* * *} \\
(2.88)\end{array}$ & $\begin{array}{l}10.52 * * * \\
(2.90)\end{array}$ & $\begin{array}{c}10.23^{* * *} \\
(2.81)\end{array}$ \\
\hline Constant & $\begin{array}{l}-85.64 * \\
(-1.81)\end{array}$ & $\begin{array}{l}-71.34 \\
(-1.50)\end{array}$ & $\begin{array}{l}-70.25 \\
(-1.47)\end{array}$ & $\begin{array}{l}-116.6^{* *} \\
(-2.01)\end{array}$ & $\begin{array}{l}-118.3^{* *} \\
(-2.03)\end{array}$ & $\begin{array}{l}-113.6^{*} \\
(-1.95)\end{array}$ \\
\hline$R^{2}$ & 0.219 & 0.205 & 0.199 & 0.486 & 0.484 & 0.482 \\
\hline$F$ & 6.794 & 6.272 & 6.009 & 22.22 & 22.04 & 21.83 \\
\hline$N$ & 527 & 527 & 527 & 511 & 511 & 511 \\
\hline
\end{tabular}

Note: Significance levels: ${ }^{*} p<0.10,{ }^{* *} p<0.05$ and ${ }^{* * *} p<0.01$. $t$-statistics in parentheses. All models include country and year fixed effects.

Table 2. Impacts of natural disasters and resilience factors on structural transformation.

\begin{tabular}{|c|c|c|c|c|c|c|}
\hline & (1) & (2) & (3) & (4) & (5) & (6) \\
\hline & \multicolumn{3}{|c|}{$\%$ of Non-Agriculture in GDP } & \multicolumn{3}{|c|}{$\%$ of Non-Agriculture in Employment } \\
\hline Natural disasters & $\begin{array}{c}0.000753 \\
(0.86)\end{array}$ & $\begin{array}{c}0.000590 \\
(1.09)\end{array}$ & $\begin{array}{c}0.000905^{* *} \\
(2.06)\end{array}$ & $\begin{array}{c}-0.00372^{* * *} \\
(-3.71)\end{array}$ & $\begin{array}{c}-0.000667 \\
(-1.07)\end{array}$ & $\begin{array}{c}-0.000759 \\
(-1.51)\end{array}$ \\
\hline Governance factor & $\begin{array}{c}1.989^{* * *} \\
(3.84)\end{array}$ & & & $\begin{array}{l}0.726 \\
(1.17)\end{array}$ & & \\
\hline Socio-economic assets factor & & $\begin{array}{c}1.319 * * \\
(2.44)\end{array}$ & & & $\begin{array}{l}1.174^{*} \\
(1.85)\end{array}$ & \\
\hline Economic and political stability factor & & & $\begin{array}{l}-0.0158 \\
(-0.05)\end{array}$ & & & $\begin{array}{l}-0.421 \\
(-1.13)\end{array}$ \\
\hline (Governance factor) X (natural disasters) & $\begin{array}{c}-0.000142 \\
(-0.16)\end{array}$ & & & $\begin{array}{c}-0.00327 * * * \\
(-3.28)\end{array}$ & & \\
\hline (Socio-economic assets factor) X (natural disasters) & & $\begin{array}{c}0.000709 \\
(0.92)\end{array}$ & & & $\begin{array}{c}-0.000488 \\
(-0.55)\end{array}$ & \\
\hline (Economic and political stability factor) X (natural disasters) & & & $\begin{array}{c}-0.00000768 \\
(-0.01)\end{array}$ & & & $\begin{array}{c}-0.000827 \\
(-1.39)\end{array}$ \\
\hline $\log ($ population) & $\begin{array}{c}9.821^{* * *} \\
(3.28)\end{array}$ & $\begin{array}{c}8.862 * * * \\
(2.95)\end{array}$ & $\begin{array}{c}8.467 * * * \\
(2.80)\end{array}$ & $\begin{array}{c}10.41 * * * \\
(2.91)\end{array}$ & $\begin{array}{c}10.37^{* * *} \\
(2.87)\end{array}$ & $\begin{array}{c}9.913^{* * *} \\
(2.75)\end{array}$ \\
\hline Constant & $\begin{array}{l}-77.66 \\
(-1.63)\end{array}$ & $\begin{array}{l}-62.15 \\
(-1.30)\end{array}$ & $\begin{array}{l}-55.92 \\
(-1.16)\end{array}$ & $\begin{array}{l}-116.2^{* *} \\
(-2.03)\end{array}$ & $\begin{array}{c}-115.9 * * \\
(-2.00)\end{array}$ & $\begin{array}{l}-108.5^{*} \\
(-1.88)\end{array}$ \\
\hline$R^{2}$ & 0.212 & 0.199 & 0.187 & 0.496 & 0.487 & 0.487 \\
\hline$F$ & 6.536 & 6.039 & 5.574 & 23.07 & 22.28 & 22.30 \\
\hline$N$ & 527 & 527 & 527 & 511 & 511 & 511 \\
\hline
\end{tabular}

Note: Significance levels: ${ }^{*} p<0.10,{ }^{* *} p<0.05$ and ${ }^{* * *} p<0.01 . t$-statistics in parentheses. All models include country and year fixed effects. 
Table 3. Impacts of terrorism shocks and resilience factors on structural transformation.

\begin{tabular}{|c|c|c|c|c|c|c|}
\hline & (1) & (2) & (3) & (4) & (5) & (6) \\
\hline & \multicolumn{3}{|c|}{$\%$ of Non-Agriculture in GDP } & \multicolumn{3}{|c|}{$\begin{array}{c}\% \text { of Non-Agriculture in } \\
\text { Employment }\end{array}$} \\
\hline Terrorism & $\begin{array}{c}-0.333^{* * *} \\
(-4.78)\end{array}$ & $\begin{array}{c}-0.302^{* * *} \\
(-4.41)\end{array}$ & $\begin{array}{c}-0.0943 \\
(-1.11)\end{array}$ & $\begin{array}{l}-0.102 \\
(-1.23)\end{array}$ & $\begin{array}{l}-0.0547 \\
(-0.68)\end{array}$ & $\begin{array}{l}0.173^{*} \\
(1.74)\end{array}$ \\
\hline Governance factor & $\begin{array}{c}2.036^{* * *} \\
(4.05)\end{array}$ & & & $\begin{array}{l}0.488 \\
(0.79)\end{array}$ & & \\
\hline Socio-economic assets factor & & $\begin{array}{c}1.289 * * \\
(2.43)\end{array}$ & & & $\begin{array}{c}1.183 \text { * } \\
(1.87)\end{array}$ & \\
\hline Economic and political stability factor & & & $\begin{array}{l}-0.323 \\
(-1.01)\end{array}$ & & & $\begin{array}{l}-0.577 \\
(-1.52)\end{array}$ \\
\hline (Governance factor) X (terrorism) & $\begin{array}{c}-0.224^{* *} \\
(-2.53)\end{array}$ & & & $\begin{array}{c}-0.230^{* *} \\
(-2.19)\end{array}$ & & \\
\hline (Socio-economic assets factor) $\mathrm{X}$ (terrorism) & & $\begin{array}{c}-0.229 * * \\
(-2.14)\end{array}$ & & & $\begin{array}{l}-0.200 \\
(-1.59)\end{array}$ & \\
\hline (Economic and political stability factor) $\mathrm{X}$ (terrorism) & & & $\begin{array}{l}0.133 \text { * } \\
(1.65)\end{array}$ & & & $\begin{array}{c}0.179 * \\
(1.90)\end{array}$ \\
\hline $\log ($ population) & $\begin{array}{c}12.50 \text { *** } \\
(4.19)\end{array}$ & $\begin{array}{c}11.47^{* * *} \\
(3.81)\end{array}$ & $\begin{array}{c}10.77^{* * * *} \\
(3.57)\end{array}$ & $\begin{array}{c}10.61^{* * *} \\
(2.89)\end{array}$ & $\begin{array}{c}10.72 * * * \\
(2.91)\end{array}$ & $\begin{array}{c}10.01^{* * *} \\
(2.73)\end{array}$ \\
\hline Constant & $\begin{array}{c}-119.7^{* *} \\
(-2.53)\end{array}$ & $\begin{array}{c}-103.1^{* *} \\
(-2.16)\end{array}$ & $\begin{array}{l}-92.31 \text { * } \\
(-1.93)\end{array}$ & $\begin{array}{c}-119.5^{* *} \\
(-2.03)\end{array}$ & $\begin{array}{c}-121.4^{* *} \\
(-2.06)\end{array}$ & $\begin{array}{c}-110.2 \text { * } \\
(-1.88)\end{array}$ \\
\hline$R^{2}$ & 0.246 & 0.227 & 0.216 & 0.486 & 0.487 & 0.486 \\
\hline$F$ & 7.927 & 7.129 & 6.681 & 22.19 & 22.25 & 22.20 \\
\hline$N$ & 527 & 527 & 527 & 511 & 511 & 511 \\
\hline
\end{tabular}

Note: Significance levels: ${ }^{*} p<0.10,{ }^{* *} p<0.05$ and ${ }^{* * *} p<0.01$. $t$-statistics in parentheses. All models include country and year fixed effects.

\subsection{Effects of Shocks on the Pace of Structural Transformation and the Role of Resilience}

In Table 1, we examine how the derived measures of resilience obtained through factor analysis mitigate the negative impacts of shocks on structural transformation. Models 1 through 3 report results for the percentage of the non-agricultural sector in GDP as the dependent variable while, in Models 4 through 6, the percentage contribution of the non-agricultural sector in employment is the dependent variable. Based on the Kaiser criterion, a commonly used standard in factor analysis, we choose three resilience factors. As shown in Appendix A Table A2, Factor 1 is positively correlated with all five world governance indicators. Therefore, we dub Factor 1 as the "governance factor". Factor 2 is positively correlated with agricultural land and health expenditure as a percent of GDP. We dub Factor 2 as the "socio-economic assets factor". Factor 3 is positively correlated with trade openness, FDI inflow, WGI political stability and WGI control of corruption. We dub Factor 3 as the "political and economic stability factor".

Models 1 and 2 in Table 1 show that the incidence of armed conflicts has a significant and negative impact on the percentage contribution of the non-agricultural sector to GDP. This suggests that conflict shocks tend to slow down the pace of structural transformation for our sample for SSA countries from 2000 to 2018. Our finding that armed conflicts increase the share of agriculture in GDP implies that, while agriculture is often destroyed in conflict-affected areas, the broader impacts are even more negative for other sectors of the economy.

On the other hand, the measures of resilience, mainly governance and socio-economic assets factors, accelerate the pace of structural transformation, as indicated by the significant and positive coefficients in Models 1 and 2. Unexpectedly, the interaction terms show no significant effects, suggesting that, while they independently help bolster the pace of structural transformation, the resilience factors do not help in mitigating the negative impacts of conflict shocks for the sample period. We primarily attribute this to the unduly destructive nature of armed conflicts. They destroy physical and social infrastructure in all sectors and affected communities and may render standard resilience-building factors 
incapable of cushioning the effects of conflict by destroying or eroding them. We know that, unlike other shocks, armed conflicts tend to destroy democratic institutions, erode good governance, disrupt political stability and create law and order disruptions, all of which are fundamental to resilience building. Only those resilience factors that can withstand armed conflict are the ones that have the potential to mitigate the impacts of such conflicts.

As shown in Models 4 through 6 in Table 1, armed conflict shocks have no significant effects on the employment dimension of structural transformation or the employment share of the non-agricultural sector. This, combined with the results from Models 1 and 2 , suggests that, while armed conflicts slow down the pace of structural transformation, as measured through the non-agricultural sector's share of GDP, it does not affect the share of employment in non-agricultural sectors. Armed conflicts have been shown to help eliminate some of the labor redundancy in agriculture. We know from previous studies that displaced, small-scale farmers from conflict-ridden areas often leave their agricultural land behind which, in turn, gets acquired by larger-scale farmers who are more efficient in their labor allocation. In addition, armed conflicts tend to force those small-scale farmers to move from rural areas to urban centers where agricultural land is scarce, and they are not able to readily compete for farm or non-farm employment opportunities. However, armed conflicts can also result in lost employment for non-agricultural workers. So, in general, our results suggest that the effects of armed conflicts on sectoral employment shares could be offsetting. As with Models 1 and 2, the resilience factors do not show any significant impacts on the percentage of non-agriculture in employment. So, in general, neither conflict-related nor resilience factors have any bearing on labor movements that influence structural transformation.

In Table 2, we examine the impacts of natural disasters on structural transformation. The incidence of natural disasters has no significant effect on the percentage contribution of the non-agriculture sector to GDP, except in Model 3, where the variable shows a positive and significant effect. This result suggests that, unlike conflicts, natural disasters do not affect the inter-sectoral shifts in the structure of output at the country level. Natural disasters, such as floods and droughts, which tend to be somewhat localized, may affect all sectors equally in a particular location, but not show effects that are significant enough at the national level compared with armed conflicts, which tend to be more effective in throwing a country off its transformation path. Once again, resilience factors accelerate structural transformation, as measured by the percentage of the non-agricultural sector in GDP. None of the interaction terms have significant effects on the dependent variable, suggesting their inability to mitigate the negative impacts of natural disasters. In addition, more populous countries are likely to undergo faster structural transformation.

Finally, Table 3 presents the results of the impacts of terrorism shocks on structural transformation. The results are very similar to those reported in Table 1 on armed conflicts. The incidence of terrorism decelerates the pace of structural transformation in SSA countries while resilience factors accelerate the structural transformation pace. In Models 1 and 2, the interaction terms show a negative and significant association with the dependent variable. This is intriguing. This suggests that the impacts of terrorism are so devastating that resilience factors do not offer any mitigative effects. This result hints at the non-exogenous nature of terrorism as a macro-level shock. Previous studies suggest that terrorism thrives in more democratic environments and states with voice and adequate freedom for the press. Hence, some of the resilience factors (e.g., voice and accountability and government effectiveness) might, in fact, worsen the negative impacts of terrorism through the role of the media in spreading fear and uncertainty among people.

In Tables A3-A6, we present the results of our robustness checks, where the variables measuring the pace of structural transformation are regressed on the shocks and the resilience-related individual variables. The results confirm the findings from the factor analysis. In Tables A3-A6, both conflict and terrorism variables negatively impact on the percentage contribution of the non-agricultural sectors to GDP and employment. Similarly, WGI indicators, especially political stability, government effectiveness, regulatory quality 
and control of corruption variables, accelerate the pace of structural transformation in GDP and employment, confirming our results using factor analysis. As an alternate shock measure, we also replace the incidence of shocks with the number of casualties suffered during the shocks. The results remain consistent as shown in Appendix B Table A7.

\subsection{Empirical Results-Discussion}

The impacts of armed conflicts and other shocks on select aspects of the economy are well documented in the literature [81,82]. However, at both the national and regional levels, the impacts of such shocks on the agricultural sector and its relative contribution to the overall economy is not well understood [81,83]. Our study attempts to fill this gap while focusing on the impacts on structural transformation, a desirable consequence of agricultural growth in a country. While our findings are based on data from sub-Saharan African countries, they also add to the broader literature on other parts of the developing world, including South America [65,84], South Asia [85-87] and the Middle East [88,89].

Our primary finding, that the negative impacts of shocks on agriculture is relatively less pronounced when compared with other sectors of the economy, is consistent with the extant literature. Extant literature would suggest that individuals and households in active conflict zones adopt different coping strategies in response to exposure to violence [81]. Such strategies include shifts in crop production portfolios, labor reallocation, destroying or hiding livestock (and other visible assets), changes in land-use patterns, economic cooperation with local ruling groups and other activities that minimize victim risks and uncertainty $[53,58,85,90,91]$. These strategies, when implemented effectively, help farmers to protect their productivity, food security and livelihoods. Similar patterns were also visible during the recent COVID-19 pandemic, when the agricultural sector was found to be more resilient than other sectors of the economy [35,92,93].

Our study also contributes to the literature which associates armed conflicts with structural transformation at the macro level. Given that land is an immobile asset, nonstate actors can easily conquer it and use it to create parallel states, a common feature in many past and ongoing armed conflicts in Africa [94,95]. Similarly, progress with structural transformation can reduce the relative share of immobile assets in the economy, thereby raising the costs of traditional territorial conflicts $[42,43]$. Our findings hint at the presence of a vicious circle which makes it difficult for countries with limited achievement of structural transformation to escape extended periods of unrest and conflicts.

\section{Summary and Conclusions}

Existing evidence of the impacts of shocks on the pace of structural transformation is limited. In this paper, using the contributions of agriculture to national income and employment as indicators of the extent of structural transformation, we explore if selected shocks slow down the pace of structural transformation. In general, we find that conflict and terrorism shocks slow down the pace of structural transformation, as measured through the percentage contribution of agriculture to GDP. However, on the employment dimension of structural transformation, we do not find that conflicts or terrorism affects the pace of structural transformation.

We, however, find that natural disasters generally show no adverse effects. We attribute the difference to the notion that conflict and terrorism tend to be more invasive, more deeply rooted, more retarding of gains previously made through good governance and economic liberalization policies and have much deeper negative conditions that slow down structural transformation than natural disasters. As outcomes of nature, not human activities or human constructs, natural disasters tend to be less systematic and less endemic, especially at the national level. Besides, the capacity of emergency management agencies to deal with natural disasters is probably easier to build than the capacity to mitigate the effects of conflict and terrorism. This is reflected in the fact that despite the growing incidence of natural disasters and the number of people affected, resulting casualties have trended downward in the last few decades in Africa [2]. For example, awareness and 
infrastructure in place for post-natural disaster redevelopment and reconstruction are well advanced, while similar structures for post-conflict redevelopment and reconstruction are mostly at their infancy.

Given the growing incidence of terrorism and other conflict shocks in Africa, our results suggest the need to take them seriously as detractors from the long-term goal of country self-reliance. Our finding that resilience factors help to work independently to bolster economies is encouraging. Our finding, however, that resilience factors do not help to mitigate the negative effects of conflict on the pace of structural transformation, measured though agriculture's share of GDP, is not encouraging. More research is needed to find appropriate measures of resilience in the face of armed conflicts, but also terrorism.

In conclusion, we offer the following recommendation. First, more detailed work is needed on the macroeconomic impacts of shocks and the mitigating effects of resilience. Second, a deeper look into the roles of shocks, beyond the three that we examine here, is needed. Third, more research on specific resilience strategies and their potential to cushion countries' economies from shocks is needed. Finally, we urge deeper investigation into the resilience framework as a tool for hastening countries' progress toward self-reliance.

Author Contributions: Conceptualization, A.A. and L.F.; Data curation, J.G.; Formal analysis, J.G.; Software, J.G.; Writing — review \& editing, A.A., L.F., K.F. and T.J. All authors have read and agreed to the published version of the manuscript.

Funding: This research received no external funding.

Institutional Review Board Statement: Not applicable.

Informed Consent Statement: Not applicable.

Data Availability Statement: The data will be provided upon request.

Conflicts of Interest: The authors declare no conflict of interest.

\section{Appendix A}

Table A1. Summary statistics.

\begin{tabular}{cccccc}
\hline Variable & N & Mean & S. D & Min & Max \\
\hline GDP per capita & 1020 & 2507.37 & 3199.03 & 194.87 & $20,532.95$ \\
\% of non-agriculture in GDP & 989 & 79.17 & 14.16 & 20.96 & 99.11 \\
\% of non-agriculture in & 1060 & 50.77 & 22.33 & 7.70 & 95.40 \\
employment & 1080 & 0.29 & 0.55 & 0.00 & 3.00 \\
Armed conflicts & 1080 & 122.60 & 718.52 & 0.00 & $20,011.00$ \\
Natural disasters & 1080 & 0.92 & 2.83 & 0.00 & 39.00 \\
Terrorist attacks & 961 & 42.49 & 29.07 & 1.24 & 100.00 \\
Access to electricity & 884 & 46.77 & 22.04 & 3.26 & 80.92 \\
Agricultural land (\% of total land) & 975 & 74.98 & 40.90 & 19.10 & 348.00 \\
Trade openness & 921 & 5.48 & 2.30 & 1.26 & 20.41 \\
Health expenditure as a \% of GDP & 845 & -782.00 & 2050.00 & $-25,100.00$ & 8750.00 \\
FDI inflow (in millions of US \$) & 815 & 99.88 & 21.93 & 23.36 & 149.31 \\
Primary school enrollment rate & 1014 & -0.64 & 0.74 & -2.23 & 1.00 \\
WGI (voice and accountability) & 1016 & -0.57 & 0.91 & -3.31 & 1.28 \\
WGI (political stability) & 1016 & -0.76 & 0.64 & -2.48 & 1.06 \\
WGI (government effectiveness) & 1016 & -0.72 & 0.63 & -2.65 & 1.13 \\
WGI (regulatory quality) & 1080 & -0.60 & 0.62 & -1.87 & 1.22 \\
WGI (control of corruption) & & & & & \\
\hline
\end{tabular}


Table A2. Factor analysis: contributions of individual variables to factors.

\begin{tabular}{cccc}
\hline Variable & Factor1 & Factor2 & Factor3 \\
\hline Access to electricity & 0.4206 & -0.5497 & 0.0312 \\
Agricultural land (\% of total land) & 0.0649 & 0.4616 & -0.2719 \\
Trade Openness & 0.1936 & -0.2191 & 0.4077 \\
Health expenditure as a \% of GDP & 0.0832 & 0.589 & 0.024 \\
FDI & -0.138 & 0.2398 & 0.3339 \\
Primary school enrollment rate & 0.1125 & 0.2697 & 0.117 \\
WGI (voice and accountability) & 0.6855 & 0.0771 & 0.1758 \\
WGI (political stability) & 0.6426 & -0.0331 & 0.5849 \\
WGI (government effectiveness) & 0.9515 & -0.1521 & 0.0415 \\
WGI (regulatory quality) & 0.931 & 0.0741 & -0.125 \\
WGI (control of corruption) & 0.8476 & -0.023 & 0.3453 \\
\hline
\end{tabular}

\section{Appendix B. Robustness Checks}

Table A3. Mitigating impacts of resilience on conflict shocks (individual resilience variables).

\begin{tabular}{|c|c|c|c|c|c|}
\hline & \multicolumn{5}{|c|}{ Dependent Variable $=\%$ of Non-Agriculture in GDP } \\
\hline & (1) & (2) & (3) & (4) & (5) \\
\hline Conflicts & $\begin{array}{l}-2.177^{* * *} \\
(-3.70)\end{array}$ & $\begin{array}{l}-0.626 \\
(-0.85)\end{array}$ & $\begin{array}{l}-1.601 * \\
(-1.76)\end{array}$ & $\begin{array}{l}-1.939 * * \\
(-2.47)\end{array}$ & $\begin{array}{l}-1.583 * \\
(-1.82)\end{array}$ \\
\hline WGI (voice and accountability) & $\begin{array}{l}0.882 \\
(1.36)\end{array}$ & & & & \\
\hline WGI (political stability) & & $\begin{array}{c}0.968^{* *} \\
(2.43)\end{array}$ & & & \\
\hline WGI (government effectiveness) & & & $\begin{array}{l}1.339 \\
(1.57)\end{array}$ & & \\
\hline WGI (regulatory quality) & & & & $\begin{array}{l}4.116^{* * *} \\
(4.87)\end{array}$ & \\
\hline WGI (control of corruption) & & & & & $\begin{array}{c}1.816^{* *} \\
(2.19)\end{array}$ \\
\hline WGI (voice and accountability) $\times$ conflict & $\begin{array}{l}-1.410^{* *} \\
(-2.03)\end{array}$ & & & & \\
\hline WGI (political stability) $\times$ conflict & & $\begin{array}{l}0.280 \\
(0.59)\end{array}$ & & & \\
\hline WGI (government effectiveness) $\times$ conflict & & & $\begin{array}{l}-0.377 \\
(-0.41)\end{array}$ & & \\
\hline WGI (regulatory quality $) \times$ conflict & & & & $\begin{array}{l}-0.971 \\
(-1.05)\end{array}$ & \\
\hline WGI (control of corruption) $\times$ conflict & & & & & $\begin{array}{l}-0.355 \\
(-0.39)\end{array}$ \\
\hline $\log ($ population) & $\begin{array}{c}10.68^{* * *} \\
(3.38)\end{array}$ & $\begin{array}{c}9.735 * * * \\
(3.13)\end{array}$ & $\begin{array}{c}10.03 * * * \\
(3.19)\end{array}$ & $\begin{array}{l}11.28^{* * *} \\
(3.66)\end{array}$ & $\begin{array}{l}9.682 * * * \\
(3.10)\end{array}$ \\
\hline Constant & $\begin{array}{l}-89.91 * \\
(-1.80)\end{array}$ & $\begin{array}{l}-74.94 \\
(-1.52)\end{array}$ & $\begin{array}{l}-79.20 \\
(-1.59)\end{array}$ & $\begin{array}{l}-98.24^{* *} \\
(-2.01)\end{array}$ & $\begin{array}{l}-73.56 \\
(-1.49)\end{array}$ \\
\hline$R^{2}$ & 0.210 & 0.213 & 0.205 & 0.240 & 0.209 \\
\hline F-statistic & 6.442 & 6.572 & 6.259 & 7.673 & 6.417 \\
\hline$N$ & 527 & 527 & 527 & 527 & 527 \\
\hline
\end{tabular}

Notes: Significance levels: ${ }^{*} p<0.10,{ }^{* *} p<0.05$ and ${ }^{* * *} p<0.01 . t$-statistics in parentheses. All models include country and year fixed effects. 
Table A4. Mitigating impacts of resilience on terrorism shocks (individual resilience variables).

\begin{tabular}{|c|c|c|c|c|c|}
\hline & \multicolumn{5}{|c|}{ Dependent Variable $=\%$ of Non-Agriculture in GDP } \\
\hline & (1) & (2) & (3) & (4) & (5) \\
\hline Terrorism & $\begin{array}{l}-0.448^{* * *} \\
(-4.85)\end{array}$ & $\begin{array}{l}-0.220 \\
(-1.57)\end{array}$ & $\begin{array}{l}-0.445^{* * *} \\
(-3.23)\end{array}$ & $\begin{array}{c}-0.560 * * * \\
(-4.36)\end{array}$ & $\begin{array}{l}-0.476^{* * *} \\
(-3.27)\end{array}$ \\
\hline WGI (voice and accountability) & $\begin{array}{l}0.984 \\
(1.55)\end{array}$ & & & & \\
\hline WGI (political stability) & & $\begin{array}{c}1.027^{* * * *} \\
(2.62)\end{array}$ & & & \\
\hline WGI (government effectiveness) & & & $\begin{array}{l}1.743 * * \\
(2.04)\end{array}$ & & \\
\hline WGI (regulatory quality) & & & & $\begin{array}{c}4.121^{* * *} \\
(4.96)\end{array}$ & \\
\hline WGI (control of corruption) & & & & & $\begin{array}{c}2.261 * * * \\
(2.73)\end{array}$ \\
\hline WGI (voice and accountability) $\times$ terrorism & $\begin{array}{c}-0.407 * * * \\
(-3.36)\end{array}$ & & & & \\
\hline WGI (political stability) $\times$ terrorism & & $\begin{array}{l}-0.0546 \\
(-0.54)\end{array}$ & & & \\
\hline WGI (government effectiveness) $\times$ terrorism & & & $\begin{array}{c}-0.329 * * \\
(-1.99)\end{array}$ & & \\
\hline WGI (regulatory quality $) \times$ terrorism & & & & $\begin{array}{c}-0.516^{* * *} \\
(-3.17)\end{array}$ & \\
\hline WGI (control of corruption) $\times$ terrorism & & & & & $\begin{array}{l}-0.298^{* *} \\
(-2.03)\end{array}$ \\
\hline Population & $\begin{array}{l}12.63 * * * \\
(3.98)\end{array}$ & $\begin{array}{c}10.82 * * * \\
(3.44)\end{array}$ & $\begin{array}{c}11.65^{* * *} \\
(3.68)\end{array}$ & $\begin{array}{c}13.18^{* * *} \\
(4.28)\end{array}$ & $\begin{array}{c}11.65^{* * *} \\
(3.71)\end{array}$ \\
\hline Constant & $\begin{array}{c}-120.5^{* *} \\
(-2.40)\end{array}$ & $\begin{array}{l}-92.14^{*} \\
(-1.85)\end{array}$ & $\begin{array}{l}-104.7 * * \\
(-2.09)\end{array}$ & $\begin{array}{c}-128.3^{* * *} \\
(-2.63)\end{array}$ & $\begin{array}{c}-104.5^{* *} \\
(-2.10)\end{array}$ \\
\hline$R^{2}$ & 0.226 & 0.215 & 0.216 & 0.259 & 0.222 \\
\hline F-statistic & 7.071 & 6.663 & 6.673 & 8.471 & 6.911 \\
\hline$N$ & 527 & 527 & 527 & 527 & 527 \\
\hline
\end{tabular}

Note: Significance levels: ${ }^{*} p<0.10,{ }^{* *} p<0.05$ and ${ }^{* * *} p<0.01 . t$-statistics in parentheses. All models include country and year fixed effects.

Table A5. Mitigating impacts of resilience on conflict shocks (individual resilience variables).

\begin{tabular}{|c|c|c|c|c|c|}
\hline & \multicolumn{5}{|c|}{ Dependent Variable $=\%$ of Non-Agriculture in Employment } \\
\hline & (1) & (2) & (3) & (4) & (5) \\
\hline Conflicts & $\begin{array}{l}-0.879 \\
(-1.33)\end{array}$ & $\begin{array}{l}-0.556 \\
(-0.67)\end{array}$ & $\begin{array}{c}-2.058^{* *} \\
(-2.02)\end{array}$ & $\begin{array}{c}-1.814^{* *} \\
(-2.02)\end{array}$ & $\begin{array}{l}-1.558 \\
(-1.60)\end{array}$ \\
\hline WGI (voice and accountability) & $\begin{array}{l}1.054 \\
(1.44)\end{array}$ & & & & \\
\hline WGI (political stability) & & $\begin{array}{l}-0.601 \\
(-1.33)\end{array}$ & & & \\
\hline WGI (government effectiveness) & & & $\begin{array}{l}-0.324 \\
(-0.33)\end{array}$ & & \\
\hline WGI (regulatory quality) & & & & $\begin{array}{l}0.553 \\
(0.54)\end{array}$ & \\
\hline WGI (control of corruption) & & & & & $\begin{array}{l}1.394 \\
(1.46)\end{array}$ \\
\hline WGI (voice and accountability) $\mathrm{X}$ conflict & $\begin{array}{c}-1.590 * * \\
(-2.05)\end{array}$ & & & & \\
\hline WGI (political stability) $\mathrm{X}$ conflict & & $\begin{array}{l}-0.369 \\
(-0.69)\end{array}$ & & & \\
\hline WGI (government effectiveness) $\mathrm{X}$ conflict & & & $\begin{array}{c}-2.379 * * \\
(-2.32)\end{array}$ & & \\
\hline WGI (regulatory quality) $\mathrm{X}$ conflict & & & & $\begin{array}{c}-2.560 * * \\
(-2.43)\end{array}$ & \\
\hline WGI (control of corruption) $\mathrm{X}$ conflict & & & & & $\begin{array}{c}-1.934 \text { * } \\
(-1.91)\end{array}$ \\
\hline Population & $\begin{array}{c}11.01^{* * * *} \\
(2.95)\end{array}$ & $\begin{array}{c}9.385 * * \\
(2.55)\end{array}$ & $\begin{array}{c}9.527^{* * *} \\
(2.60)\end{array}$ & $\begin{array}{c}10.17^{* * *} \\
(2.77)\end{array}$ & $\begin{array}{c}9.165^{* *} \\
(2.50)\end{array}$ \\
\hline Constant & $\begin{array}{c}-125.7^{* *} \\
(-2.11)\end{array}$ & $\begin{array}{l}-100.2 * \\
(-1.71)\end{array}$ & $\begin{array}{l}-102.4 * \\
(-1.75)\end{array}$ & $\begin{array}{l}-112.4 * \\
(-1.92)\end{array}$ & $\begin{array}{l}-95.85 \\
(-1.64)\end{array}$ \\
\hline$R^{2}$ & 0.464 & 0.461 & 0.464 & 0.465 & 0.464 \\
\hline$F$-statistic & 20.33 & 20.07 & 20.34 & 20.37 & 20.36 \\
\hline$N$ & 511 & 511 & 511 & 511 & 511 \\
\hline
\end{tabular}

Note: Significance levels: ${ }^{*} p<0.10,{ }^{* *} p<0.05$ and $^{* * *} p<0.01 . t$-statistics in parentheses. All models include country and year fixed effects. 
Table A6. Mitigating impacts of resilience on terrorism shocks (individual resilience variables).

\begin{tabular}{|c|c|c|c|c|c|}
\hline & \multicolumn{5}{|c|}{ Dependent Variable $=\%$ of Non-Agriculture in Employment } \\
\hline & (1) & (2) & (3) & (4) & (5) \\
\hline Terrorism & $\begin{array}{c}-0.282 * * * \\
(-2.72)\end{array}$ & $\begin{array}{l}0.151 \\
(0.95)\end{array}$ & $\begin{array}{l}-0.248 \\
(-1.60)\end{array}$ & $\begin{array}{c}-0.384^{* * *} \\
(-2.59)\end{array}$ & $\begin{array}{l}-0.188 \\
(-1.14)\end{array}$ \\
\hline WGI (voice and accountability) & $\begin{array}{l}0.988 \\
(1.38)\end{array}$ & & & & \\
\hline WGI (political stability) & & $\begin{array}{l}-0.744 * \\
(-1.68)\end{array}$ & & & \\
\hline WGI (government effectiveness) & & & $\begin{array}{l}-0.245 \\
(-0.25)\end{array}$ & & \\
\hline WGI (regulatory quality) & & & & $\begin{array}{l}0.328 \\
(0.32)\end{array}$ & \\
\hline WGI (control of corruption) & & & & & $\begin{array}{l}1.492 \\
(1.55)\end{array}$ \\
\hline WGI (voice and accountability) $\mathrm{X}$ terrorism & $\begin{array}{c}-0.469 * * * \\
(-3.45)\end{array}$ & & & & \\
\hline WGI (political stability) $\mathrm{X}$ terrorism & & $\begin{array}{l}0.124 \\
(1.08)\end{array}$ & & & \\
\hline WGI (government effectiveness) $\mathrm{X}$ terrorism & & & $\begin{array}{l}-0.343^{*} \\
(-1.84)\end{array}$ & & \\
\hline WGI (regulatory quality) $\mathrm{X}$ terrorism & & & & $\begin{array}{c}-0.549 * * * \\
(-2.93)\end{array}$ & \\
\hline WGI (control of corruption) X terrorism & & & & & $\begin{array}{l}-0.214 \\
(-1.28)\end{array}$ \\
\hline Population & $\begin{array}{c}11.63 \text { *** } \\
(3.11)\end{array}$ & $\begin{array}{c}9.269 * * \\
(2.50)\end{array}$ & $\begin{array}{c}9.601 * * \\
(2.58)\end{array}$ & $\begin{array}{c}10.45^{* * *} \\
(2.81)\end{array}$ & $\begin{array}{c}9.785^{* * *} \\
(2.63)\end{array}$ \\
\hline Constant & $\begin{array}{c}-135.4^{* *} \\
(-2.26)\end{array}$ & $\begin{array}{l}-98.48^{*} \\
(-1.66)\end{array}$ & $\begin{array}{l}-103.5^{*} \\
(-1.74)\end{array}$ & $\begin{array}{c}-116.7^{* *} \\
(-1.97)\end{array}$ & $\begin{array}{l}-105.6 * \\
(-1.77)\end{array}$ \\
\hline$R^{2}$ & 0.473 & 0.462 & 0.462 & 0.468 & 0.462 \\
\hline F-statistic & 21.08 & 20.13 & 20.15 & 20.64 & 20.16 \\
\hline$N$ & 511 & 511 & 511 & 511 & 511 \\
\hline
\end{tabular}

Note: Significance levels: ${ }^{*} p<0.10,{ }^{* *} p<0.05$ and ${ }^{* * *} p<0.01 . t$-statistics in parentheses. All models include country and year fixed effects.

Table A7. Mitigating impacts of resilience on conflict and terrorism shocks (intensity).

\begin{tabular}{ccccc}
\hline & $\mathbf{( 1 )}$ & $\mathbf{( 2 )}$ & $\mathbf{( 3 )}$ & $\mathbf{( 4 )}$ \\
\hline & \% of Non-Agriculture in GDP & \% of Non-Agriculture in Employment \\
\hline Conflict casualty & $-0.000742^{*}$ & 0.000546 & & \\
& $(-1.86)$ & $(1.18)$ & & -0.000942 \\
Terrorism casualty & & & $-0.00359 * *$ & $(-0.46)$ \\
Population & & & $(-2.04)$ & 10.31 *** \\
& $8.147^{* * *}$ & $10.43^{* * *}$ & $9.672^{* * *}$ & $(2.83)$ \\
$R^{2}$ & $(2.71)$ & $(2.88)$ & $(3.22)$ & 0.480 \\
F-statistic & 0.196 & 0.485 & 0.216 & 21.71 \\
$N$ & 5.908 & 22.07 & 6.690 & 511
\end{tabular}

Note: Significance levels: ${ }^{*} p<0.10,{ }^{* *} p<0.05$ and ${ }^{* * *} p<0.01 . t$-statistics in parentheses. All models include country and year fixed effects.

\section{References}

1. Jayne, T.; Fox, L.; Fuglie, K.; Adelaja, A.; Anderson, P.; Ash, J.; Bertram, R.; Brooks, K.; Cohen, C.; Deaton, B.; et al. Agricultural Productivity Growth, Resilience, and Economic Transformation in Sub-Saharan Africa Implications for USAID Documents; USAID: Washington, DC, USA, 2021.

2. Adelaja, A.; George, J.; D’errico, M.; Hodbod, J.; Jones, L.P.; Jayne, T.; Mulenga, B. Growing Impacts of Shocks on Sub-Saharan Africa's Agri-Food System and the Mitigating Role of Resilience; Africa Agriculture Status Report Chapter 3; Alliance for a Green Revolution in Africa (AGRA): Nairobi, Kenya, 2021. 
3. Calderón, C.; Servén, L. Infrastructure and Economic Development in Sub-Saharan Africa. J. Afr. Econ. 2010, 19, i13-i87. [CrossRef]

4. Collier, P.; Gunning, J.W. Why Has Africa Grown Slowly? J. Econ. Perspect. 1999, 13, 3-22. [CrossRef]

5. Artadi, E.V.; Sala-I-Martin, X. The Economic Tragedy of the Xx Th Century: Growth in Africa; National Bureau of Economic Research: Cambridge, MA, USA, 2003.

6. World Bank World Development Indicators. Available online: https://data.worldbank.org/products/wdi (accessed on 30 April 2018).

7. Beegle, K.; Christiaensen, L.J. Accelerating Poverty Reduction in Africa; World Bank: Washington, DC, USA, 2019; ISBN 978-1-46481232-3.

8. Masters, W.A.; Djurfeldt, A.A.; De Haan, C.; Hazell, P.; Jayne, T.; Jirström, M.; Reardon, T. Urbanization and Farm Size in Asia and Africa: Implications for Food Security and Agricultural Research. Glob. Food Secur. 2013, 2, 156-165.

9. Diao, X.; Mcmillan, M.; Rodrik, D.; Kennedy, J.F. The Recent Growth Boom in Developing Economies: A Structural-Change Perspective; Springer: Berlin/Heidelberg, Germany, 2017.

10. Oduro, A.D.; Doss, C.R. Changing Patterns of Wealth Distribution: Evidence from Ghana. J. Dev. Stud. 2018, 54, 933-948. [CrossRef]

11. World Bank. World Governance Indicators; World Bank: Washington, DC, USA, 2021.

12. Rodrik, D. When Ideas Trump Interests: Preferences, Worldviews, and Policy Innovations. J. Econ. Perspect. 2014, 28, 189-208. [CrossRef]

13. Jayne, T.S.; Chamberlin, J.; Benfica, R. Africa's Unfolding Economic Transformation. J. Dev. Stud. 2018, 54, 777-787. [CrossRef]

14. FAO; IFAD; UNICEF; WFP; WHO. The State of Food Security and Nutrition in the World 2020. Transforming Food Systems for Affordable Healthy Diets; FAO: Rome, Italy, 2020.

15. Jayne, T.S.; Chamberlin, J.; Traub, L.; Sitko, N.; Muyanga, M.; Yeboah, F.K.; Anseeuw, W.; Chapoto, A.; Wineman, A.; Nkonde, C.; et al. Africa's Changing Farm Size Distribution Patterns: The Rise of Medium-Scale Farms. Agric. Econ. 2016, 47, 197-214. [CrossRef]

16. Filmer, D.; Fox, L. Youth Employment in Sub-Saharan Africa; World Bank: Washington DC, USA, 2014. [CrossRef]

17. McMillan, M.; Harttgen, K.; McMillan, M.; Harttgen, K. What Is Driving the "African Growth Miracle"? Working Paper Series no. 209; African Development Bank Group: Abidjan, Côte d'Ivoire, 2014.

18. Beresford, J. All Our Welfare: Towards Participatory Social Policy, by Peter Beresford. Crit. Policy Stud. 2016, 10, 489-490. [CrossRef]

19. Holleman, C.; Jackson, J.; Sánchez, M.V.; Vos, R. Sowing the Seeds of Peace for Food Security: Disentangling the Nexus between Conflict, Food Security and Peace; FAO: Rome, Italy, 2017.

20. FAO; IFAD; UNICEF; WFP; WHO. The State of Food Security and Nutrition in the World 2017. Building Resilience for Peace and Food Security; FAO: Rome, Italy, 2017.

21. FAO. The Impact of Disasters and Crises on Agriculture and Food Security: 2021; FAO: Rome, Italy, 2021.

22. Adelaja, A.; George, J. Effects of Conflict on Agriculture: Evidence from the Boko Haram Insurgency. World Dev. 2019, 117, 184-195. [CrossRef]

23. Hendrix, C.S.; Salehyan, I. Climate Change, Rainfall, and Social Conflict in Africa. J. Peace Res. 2012, 49, 35-50. [CrossRef]

24. Buhaug, H.; Benjaminsen, T.A.; Sjaastad, E.; Magnus Theisen, O. Climate Variability, Food Production Shocks, and Violent Conflict in Sub-Saharan Africa. Environ. Res. Lett. 2015, 10, 125015. [CrossRef]

25. ACLED Armed Conflict Location Event Data Project, Version 8. Available online: https://www.acleddata.com/wp-content/ uploads/2017/12/ACLED_Codebook_2017FINAL.pdf (accessed on 28 April 2018).

26. Raleigh, C.; Linke, A.; Hegre, H.; Karlsen, J. Introducing ACLED: An Armed Conflict Location and Event Dataset. J. Peace Res. 2010, 47, 651-660. [CrossRef]

27. George, J.; Adelaja, A.; Awokuse, T.O. The Agricultural Impacts of Armed Conflicts: The Case of Fulani Militia. Eur. Rev. Agric. Econ. 2021, 48, 538-572. [CrossRef]

28. George, J.; Adelaja, A. Forced Displacement and Agriculture: Implications for Host Communities. Sustainability 2021, 13, 5728. [CrossRef]

29. Jones, B.F.; Olken, B.A. Climate Shocks and Exports. Am. Econ. Rev. 2010, 100, 454-459. [CrossRef]

30. Hallegatte, S.; Bangalore, M.; Bonzanigo, L.; Fay, M.; Kane, T.; Narloch, U.; Rozenberg, J.; Treguer, D.; Vogt-Schilb, A. Shock Waves: Managing the Impacts of Climate Change on Poverty; The World Bank: Washington DC, USA, 2015.

31. Nordhagen, S.; Pascual, U. The Impact of Climate Shocks on Seed Purchase Decisions in Malawi: Implications for Climate Change Adaptation. World Dev. 2013, 43, 238-251. [CrossRef]

32. CRED. EM-DAT: The International Disaster Database. Available online: http://www.emdat.be/classification (accessed on 30 April 2018).

33. Hsiang, S.M.; Burke, M.; Miguel, E. Quantifying the Influence of Climate on Human Conflict. Science 2013, $341,1235367$. [CrossRef]

34. Mach, K.J.; Kraan, C.M.; Adger, W.N.; Buhaug, H.; Burke, M.; Fearon, J.D.; Field, C.B.; Hendrix, C.S.; Maystadt, J.-F.; O’Loughlin, J.; et al. Climate as a Risk Factor for Armed Conflict. Nature 2019, 571, 193-197. [CrossRef]

35. ILO. COVID-19 and the Impact on Agriculture and Food Security; ILO: Geneva, Switzerland, 2020. 
36. Reardon, T.; Mishra, A.; Nuthalapati, C.S.R.; Bellemare, M.F.; Zilberman, D. COVID-19's Disruption of India's Transformed Food Supply Chains. Econ. Poliit. Wkly. 2020, 55, 18-22.

37. FAO. Impact of COVID-19 on Agriculture, Food Systems and Rural Livelihoods in Eastern Africa: Policy and Programmatic Options; FAO: Rome, Italy, 2020.

38. FSIN. Global Report on Food Crises; World Food Programme: Rome, Italy, 2021.

39. D'Errico, M.; Di Giuseppe, S. Resilience Mobility in Uganda: A Dynamic Analysis. World Dev. 2018, 104, 78-96. [CrossRef]

40. Smith, L.C.; Frankenberger, T.R. Does Resilience Capacity Reduce the Negative Impact of Shocks on Household Food Security? Evidence from the 2014 Floods in Northern Bangladesh. World Dev. 2018, 102, 358-376. [CrossRef]

41. Vestby, J.; Buhaug, H.; von Uexkull, N. Why Do Some Poor Countries See Armed Conflict While Others Do Not? A Dual Sector Approach. World Dev. 2021, 138, 105273. [CrossRef]

42. Hirschman, A.O. Exit, Voice, and the State. World Politics 1978, 31, 90-107. [CrossRef]

43. Boix, C. Economic Roots of Civil Wars and Revolutions in the Contemporary World. World Politics 2008, 60, 390-437. [CrossRef]

44. START. Global Terrorism Database (GTD). Available online: http://www.start.umd.edu/data-tools/global-terrorism-databasegtd (accessed on 30 April 2018).

45. Herrendorf, B.; Rogerson, R.; Valentinyi, Á. Growth and Structural Transformation. In Handbook of Economic Growth; Elsevier: Amsterdam, The Netherlands, 2014; Volume 2, pp. 855-941. [CrossRef]

46. Timmer, C.P.; Akkus, S. The Structural Transformation as a Pathway Out of Poverty: Analytics, Empirics and Politics. SSRN Electron. J. 2008. [CrossRef]

47. De Vries, H.; Bekkers, V.; Tummers, L. Innovation in the Public Sector: A Systematic Review and Future Research Agenda. Public Adm. 2016, 94, 146-166. [CrossRef]

48. Fox, L.; Jayne, T.; Moskaleva, E. Towards Resilient, Sustainable, Transformed African Food Systems: Conceptual Framework; Africa Agriculture Status Report Chapter 2; Alliance for a Green Revolution in Africa (AGRA): Nairobi, Kenya, 2021.

49. Barrett, C.B.; Constas, M.A. Toward a Theory of Resilience for International Development Applications. Proc. Natl. Acad. Sci. USA 2014, 111, 14625-14630. [CrossRef] [PubMed]

50. Choularton, R.; Frankenberger, T.; Kurtz, J.; Nelson, S. Measuring Shocks and Stressors as Part of Resilience Measurement. Resilience Measurement Technical Working Group; Food Security Information Network: Rome, Italy, 2015.

51. Zseleczky, L.; Yosef, S. Are Shocks Really Increasing? A Selective Review of the Global Frequency, Severity, Scope, and Impact of Five Types of Shocks; International Food Policy Research Institute: Washington, DC, USA, 2014.

52. Adelaja, A.; George, J. Terrorism and Land Use in Agriculture: The Case of Boko Haram in Nigeria. Land Use Policy 2019, 88, 104116. [CrossRef]

53. Bozzoli, C.; Brück, T. Agriculture, Poverty, and Postwar Reconstruction: Micro-Level Evidence from Northern Mozambique. J. Peace Res. 2009, 46, 377-397. [CrossRef]

54. George, J.; Adelaja, A.; Weatherspoon, D. Armed Conflicts and Food Insecurity: Evidence from Boko Haram's Attacks. Am. J. Agric. Econ. 2020, 102, 114-131. [CrossRef]

55. Akresh, R.; Verwimp, P.; Bundervoet, T. Civil War, Crop Failure, and Child Stunting in Rwanda. Econ. Dev. Cult. Chang. 2011, 59, 777-810. [CrossRef]

56. Akresh, R.; Bhalotra, S.; Leone, M.; Osili, U.O. War and Stature: Growing Up during the Nigerian Civil War. Am. Econ. Rev. 2012, 102, 273-277. [CrossRef]

57. Kondylis, F. Conflict Displacement and Labor Market Outcomes in Post-War Bosnia and Herzegovina. J. Dev. Econ. 2010, 93, 235-248. [CrossRef]

58. Arias, M.A.; Ibáñez, A.M.; Zambrano, A. Agricultural Production amid Conflict: Separating the Effects of Conflict into Shocks and Uncertainty. World Dev. 2019, 119, 165-184. [CrossRef]

59. Esen, O.; Binatli, A.O. The Impact of Syrian Refugees on the Turkish Economy: Regional Labour Market Effects. Soc. Sci. 2017, 6, 129. [CrossRef]

60. Ruiz, I.; Silva, C.V. The Labor Market Impacts of Forced Migration. Am. Econ. Rev. 2015, 105, 581-586. [CrossRef]

61. Calderón-Mejía, V.; Ibáñez, A.M. Labour Market Effects of Migration-Related Supply Shocks: Evidence from Internal Refugees in Colombia. J. Econ. Geogr. 2016, 16, 695-713. [CrossRef]

62. Foged, M.; Peri, G. Immigrants' Effect on Native Workers: New Analysis on Longitudinal Data. Am. Econ. J. Appl. Econ. 2016, 8, 1-34. [CrossRef]

63. Alix-Garcia, J.; Walker, S.; Bartlett, A.; Onder, H.; Sanghi, A. Do Refugee Camps Help or Hurt Hosts? The Case of Kakuma, Kenya. J. Dev. Econ. 2018, 130, 66-83. [CrossRef]

64. Balkan, B.; Tumen, S. Immigration and Prices: Quasi-Experimental Evidence from Syrian Refugees in Turkey. J. Popul. Econ. 2016, 29, 657-686. [CrossRef]

65. Depetris-Chauvin, E.; Santos, R.J. Unexpected Guests: The Impact of Internal Displacement Inflows on Rental Prices in Colombian Host Cities. J. Dev. Econ. 2018, 134, 289-309. [CrossRef]

66. Chapagain, T.; Raizada, M.N. Impacts of Natural Disasters on Smallholder Farmers: Gaps and Recommendations. Agric. Food Secur. 2017, 6, 39. [CrossRef]

67. FAO. Food Security and Protracted Crisis; FAO: Rome, Italy, 2006. 
68. Israel, D.C.; Briones, R.M. Impacts of Natural Disasters on Agriculture, Food Security, and Natural Resources and Environment in the Philippines; Philippine Institute for Development Studies (PIDS): Makati, Philippines, 2012.

69. Rapsomanikis, G. The Economic Lives of Smallholder Farmers: An Analysis Based on Household Data from Nine Countries; FAO: Rome, Italy, 2015.

70. Popp, A. The Effects of Natural Disasters on Long Run Growth. Major Themes Econ. 2006, 8, 61-82.

71. Mottaleb, K.A.; Mohanty, S.; Hoang, H.T.K.; Rejesus, R.M. The Effects of Natural Disasters on Farm Household Income and Expenditures: A Study on Rice Farmers in Bangladesh. Agric. Syst. 2013, 121, 43-52. [CrossRef]

72. Ainehvand, S.; Raeissi, P.; Ravaghi, H.; Maleki, M. Natural Disasters and Challenges toward Achieving Food Security Response in Iran. J. Educ. Health Promot. 2019, 8, 51. [CrossRef] [PubMed]

73. Doocy, S.; Leidman, E.; Aung, T.; Kirsch, T. Household Economic and Food Security after the 2010 Pakistan Floods. Food Nutr. Bull. 2013, 34, 95-103. [CrossRef]

74. Cuaresma, J.C. Natural Disasters and Human Capital Accumulation. World Bank Econ. Rev. 2010, 24, 280-302. [CrossRef]

75. Wouter Botzen, W.J.; Deschenes, O.; Sanders, M. The Economic Impacts of Natural Disasters: A Review of Models and Empirical Studies. Rev. Environ. Econ. Policy 2019, 13, 167-188. [CrossRef]

76. Nchanji, E.B.; Lutomia, C.K. Regional Impact of COVID-19 on the Production and Food Security of Common Bean Smallholder Farmers in Sub-Saharan Africa: Implication for SDG's. Glob. Food Secur. 2021, 29, 100524. [CrossRef]

77. Béné, C. Resilience of Local Food Systems and Links to Food Security-A Review of Some Important Concepts in the Context of COVID-19 and Other Shocks. Food Secur. 2020, 12, 805-822. [CrossRef]

78. FAO. RIMA-II: Resilience Index Measurement and Analysis II; FAO: Rome, Italy, 2016.

79. Frankenberger, T.R.; Smith, L.C. Ethiopia Pastoralist Areas Resilience Improvement and Market Expansion (PRIME) Project Impact Evaluation Report of the Interim Monitoring; USAID: Washington DC, USA, 2015.

80. Greene, R.R.; Greene, D.G. Resilience in the Face of Disasters: Bridging Micro-and Macro-Perspectives. J. Hum. Behav. Soc. Environ. 2009, 19, 1010-1024. [CrossRef]

81. Martin-Shields, C.P.; Stojetz, W. Food Security and Conflict: Empirical Challenges and Future Opportunities for Research and Policy Making on Food Security and Conflict. World Dev. 2019, 119, 150-164. [CrossRef]

82. Verwimp, P.; Justino, P.; Brück, T. The Microeconomics of Violent Conflict. J. Dev. Econ. 2019, 141, 102297. [CrossRef]

83. Blattman, C.; Miguel, E. Civil War. J. Econ. Lit. 2010, 48, 3-57. [CrossRef]

84. Garcia Corrales, L.M.; Avila Rangel, H.; Gutierrez Llantoy, R. Land-Use and Socioeconomic Changes Related to Armed Conflicts: A Colombian Regional Case Study. Environ. Sci. Policy 2019, 97, 116-124. [CrossRef]

85. Menon, N.; Rodgers, Y.; van der, M. War and Women's Work: Evidence from the Conflict in Nepal. J. Confl. Resolut. 2013, 59, 51-73. [CrossRef]

86. Pivovarova, M.; Swee, E.L. Quantifying the Microeconomic Effects of War Using Panel Data: Evidence from Nepal. World Dev. 2015, 66, 308-321. [CrossRef]

87. Tranchant, J.-P.; Justino, P.; Müller, C. Political Violence, adverse shocks and Child Malnutrition: Empirical Evidence from Andhra Pradesh, India. Econ. Hum. Biol. 2020, 39, 100900. [CrossRef]

88. Jaafar, H.H.; Woertz, E. Agriculture as a Funding Source of ISIS: A GIS and Remote Sensing Analysis. Food Policy 2016, 64, 14-25. [CrossRef]

89. Guerrero-Serdán, G. The Effects of the War in Iraq on Nutrition and Health: An Analysis Using Anthropometric Outcomes of Children; HiCN Working Paper: Brighton, UK, 2009.

90. Gafaro, M.; Justino, P.; Ibbbez, A.M. Collective Action and Armed Group Presence in Colombia. SSRN Electron. J. 2014. [CrossRef]

91. Verpoorten, M. Household Coping in War- and Peacetime: Cattle Sales in Rwanda, 1991-2001. J. Dev. Econ. 2009, 88, 67-86. [CrossRef]

92. Devereux, S.; Béné, C.; Hoddinott, J. Conceptualising COVID-19's Impacts on Household Food Security. Food Secur. 2020, 12, 769-772. [CrossRef] [PubMed]

93. Amankwah, A.; Gourlay, S. Impact of Covid-19 Crisis on Agriculture: Evidence from Five Sub-Saharan African Countries; World Bank blogs: Washington, DC, USA, 2021.

94. Pinos, J.C.; Radil, S.M. The Territorial Contours of Terrorism: A Conceptual Model of Territory for Non-State Violence. Terror. Political Violence 2018, 32, 1027-1046. [CrossRef]

95. Elden, S. Terror and Territory: The Spatial Extent of Sovereignty; University of Minnesota Press: Minneapolis, MN, USA, 2009; ISBN 9780816654840 . 